[Article]

\title{
基于稀土配合物的有机光盲型紫外探测器
}

\author{
李凌亮张福俊 ${ }^{*}$ 王梓轩安桥石 王 健徐 征 \\ (北京交通大学发光与光信息技术教育部重点实验室, 北京 100044)
}

\begin{abstract}
摘要：使用二苯甲酰甲烷-二苯菲罗啉-销 $\left(\mathrm{Eu}(\mathrm{DBM})_{3} \mathrm{BPhen}\right)$ 作为电子给体和 $[6,6]$-苯基-C61-丁酸酸甲酯 ([60]PCBM)作为电子受体制备了一种新型的有机光盲型紫外探测器. 在光强为 $2.1 \mathrm{~mW} \cdot \mathrm{cm}^{-2}$ 且波长为 $360 \mathrm{~nm}$ 的紫外光照射下, 获得了 $26 \mathrm{~mA} \cdot \mathrm{W}^{-1}$ 的响应度和 $9.1 \%$ 的外量子效率, 这是由于 $E u(D B M)_{3} B P h e n$ 的强紫外光 吸收能力和长达 $300 \mu \mathrm{s}$ 的激子寿命使得给受体界面处具有较高的激子解离率. 在把[60]PCBM 掺入 Eu(DBM) BPhen 后, 观察到了明显的光致发光猝灭和光电导现象. 由于材料较低的载流子迁移率和受陷激子的缓慢释 放, 在紫外光照射关闭后, 观察到了较强的持续光电导现象.
\end{abstract}

关键词: 有机光盲; 紫外探测器; 持续光电导

中图分类号: 0644; 0472; 0472

\section{Organic Visible-Blind Ultraviolet Photodetectors Based on Rare Earth Complex}

\author{
LI Ling-Liang ZHANG Fu-Jun* \\ WANG Zi-Xuan \\ AN Qiao-Shi WANG Jian XU Zheng \\ (Key Laboratory of Luminescence and Optical Information, Ministry of Education, Beijing Jiaotong University, \\ Beijing 100044, P. R. China)
}

\begin{abstract}
A new type of organic visible-blind ultraviolet (UV) photodetector based on tri(dibenzoylmethane)(4, 7-biphenyl-1,10-phenanthroline)europium (III) [Eu(DBM) ${ }_{3}$ BPhen] as an electron donor and $[6,6]$-phenylC-61-butyric acid methyl ester ([60]PCBM) as an electron acceptor was fabricated. A peak response of $26 \mathrm{~mA}$. $\mathrm{W}^{-1}$ and external quantum efficiency of $9.1 \%$ were obtained under illumination with $360 \mathrm{~nm} \mathrm{UV}$ light at 2.1 $\mathrm{mW} \cdot \mathrm{cm}^{-2}$. This was because of the high UV absorption of $\mathrm{Eu}(\mathrm{DBM})_{3} \mathrm{BPhen}$ and the long lifetime, $300 \mu \mathrm{s}$, of $\mathrm{Eu}^{3+}$ ions, resulting in high exciton dissociation efficiency. Distinct photoluminescence quenching and photoconductivity of $\mathrm{Eu}(\mathrm{DBM})_{3} \mathrm{BPhen}$ were obtained by doping with [60]PCBM. A strong persistent photoconductivity was observed, which could be attributed to low charge carrier transportation and slow release of trapped exciton states in the blend films after the UV light is turned off.
\end{abstract}

Key Words: Organic visible-blind; Ultraviolet photodetector; Persistent photoconductivity

\section{Introduction}

Ultraviolet photodetectors (UV-PDs) could absorb UV light energy and convert it into electrical response that can be measured. Although inorganic semiconductor-based UV detectors provide many advantages, their manufacturing is expensive and complicated. Organic UV-PDs have attracted more and more attention due to their light weight, ease of large scale manufacture, wide selection of materials, mechanical flexibility, and low-cost fabrication compared with their inorganic counterparts. ${ }^{1,2}$ Strong absorption ability, high charge carrier mobility,

Received: July 29, 2013; Revised: October 30, 2013; Published on Web: October 30, 2013.

"Corresponding author. Email: fjzhang@bjtu.edu.cn; Tel: +86-10-51684908.

The project was supported by the Fundamental Research Funds for the Central Universities, China (2013JBZ004), Beijing Natural Science

Foundation, China (2122050), and National Natural Science Foundation of China (613770029).

高等学校基本科研业务基金(2013JBZ004), 北京市自然科学基金(2122050)及国家自然科学基金(613770029)资助项目

(c) Editorial office of Acta Physico-Chimica Sinica 
and energy level convenience of donor and acceptor materials are important parameters while using organic semiconductors as active layers in UV-PDs. To achieve higher response, there has been many works focused on organic UV-PDs using strong absorption ability and high hole mobility materials such as, 4, 4',4"-tri-(2-methylphenyl phenylamino) triphenylaine (m-MTDATA), 1,1-bis(di-4-tolylaminophenyl)cyclohexane (TAPC), $N, N$ bis-(1-naphthyl)- $N, N$-biphenyl-1,1-biphenyl-4,4-diamine (NPB), 3,6-di(1,1:3,1-terphenyl-5-yl)-9-(2-ethyl) hexylcarbazole (PCP) as donors. Li et al. ${ }^{3}$ reported an organic visibleblind UV-PD with long term stability and a peak response of $514 \mathrm{~mA} \cdot \mathrm{W}^{-1}$ at $365 \mathrm{~nm}$, using m-MTDATA as a donor and aluminum(III) bis(2-methyl-8-quinolinato)4-phenylphenolate (BAlq) as an accepter, respectively. Zhang et $a l .{ }^{4}$ reported a UV-PD with a high response at $248-370 \mathrm{~nm}$ and a peak response of $180 \mathrm{~mA} \cdot \mathrm{W}^{-1}$ at $280 \mathrm{~nm}$, using NPB as a donor and 2-(4-tertbutylphenyl)-5-(4-biphenylyl)-1,3,4-oxadiazole (PBD) as an accepter, respectively. Zhang et al. ${ }^{5}$ reported a UV-PD with a narrow response width of $30 \mathrm{~nm}$ from 316 to $346 \mathrm{~nm}$ and a peak response of $0.12 \mathrm{~A} \cdot \mathrm{W}^{-1}$ at $330 \mathrm{~nm}$, using TAPC as a donor and PBD as an accepter, respectively. Wu et al. ${ }^{6}$ reported a tunable response range UV- PD by changing illumination direction from cathode or anode sides, using PCP as a donor and bis(4(4,6-diphenyl-1,3,5-triazine-2-yl)phenyl)diphenylsilane (NSN) as an acceptor.

However, UV-PDs based on rare earth complex as a donor are rarely reported. Rare earth complexes have attracted more attention because of their highly monochromatic emission and theoretical emission quantum efficiency $(100 \%)$ in organic light-emitting devices (OLEDs). ${ }^{7}$ The emission lifetime of rare earth complexes is longer than $100 \mu \mathrm{s}$, which is beneficial to exciton dissociation. ${ }^{8}$ Therefore, it may be another way to increase UV-PD's response by using rare earth complex as donor. In this paper, a solution- processed UV- PDs employing tri (dibenzoylmethane) (4,7-biphenyl-1,10-phenanthroline) europium (III) (Eu(DBM) $)_{3}$ BPhen) as an electron donor and [6,6]-phenyl-C61-butyric acid methyl ester ([60]PCBM) as an electron accepter are fabricated. The photoconductive phenomenon and response of UV-PDs were investigated.

\section{Experimental}

Indium tin oxide (ITO) coated glass substrates with a sheet resistance of $15 \Omega \cdot \square^{-1}$ (purchased from Shenzhen Jinghua Display Co., Ltd.), which were cleaned with detergent, deionedwater, and ethanol successively in ultrasonic baths for $15 \mathrm{~min}$. All substrates were dried by nitrogen-gas and were treated by UV-ozone for $5 \mathrm{~min}$ to improve the work function of ITO substrates. Organic materials $\mathrm{Eu}(\mathrm{DBM})_{3} \mathrm{BPhen}$ (purity: $>99.5 \%$, purchased from Jilin OLED Material Tech CO., Ltd.) and [60]PCBM (purity: $>99 \%$, purchased from Nichem Fine Technology CO., Ltd.) were dissolved in chloroform (purity: > $99.5 \%$ ) to prepare $20 \mathrm{mg} \cdot \mathrm{mL}^{-1}$ solution, respectively. Then $\mathrm{Eu}(\mathrm{DBM})_{3} \mathrm{BPhen}$ solution was mixed with [60]PCBM solution with the volume ratio of $1: 1$. The $\mathrm{Eu}(\mathrm{DBM})_{3} \mathrm{BPhen}$ solution and the blended solution were spin coated on the ITO glass substrates at the speed of $1500 \mathrm{r} \cdot \mathrm{min}^{-1}$ for $40 \mathrm{~s}$, respectively. Subsequently, the substrates coated with organic active layer were transferred to a vacuum chamber to prepare the aluminum (Al) cathode under $5 \times 10^{3} \mathrm{~Pa}$. The thickness of $\mathrm{Al}$ cathode is about $100 \mathrm{~nm}$ and the active area is about $3 \mathrm{~mm} \times 3 \mathrm{~mm}$ through shadow mask. The chemical structures of used organic materials and device structure schematic diagram are shown in Fig.1.

Absorption and transmittance spectra were measured by a Shimadzu UV-3101 PC spectrophotometer. Photoluminescence spectra were measured by a Perkin Elmer LS-55 spectrophotometer. Time-resolved transient PL decay was measured by a system built with a pulsed YAG laser device, a Jobin YvonSpex TRIAX 320 emission monochromator and a Tektronix TDS540D digital oscilloscope. Current-voltage ( $I-V)$ characteristic curves of the devices were recorded by a Keithley 2410 Source Meter both in the dark and under illumination of 360 $\mathrm{nm}$ monochromatic light with an intensity of $2.1 \mathrm{~mW} \cdot \mathrm{cm}^{-2}$ through ITO anode side. The photoelectric characteristic curves of fabricated UV-PD were measured by a xenon lamp as light source coupled to a monochromator. The output intensity-wavelength characteristic curve of the monochromatic light was recorded by a calibrated Newport 818 - UV power meter and an Acton SpectraPro 2150i CCD spectrometer. All the measurements were carried out in ambient atmosphere at room temperature.

\section{Results and discussion}

The absorption spectra of neat $\mathrm{Eu}(\mathrm{DBM})_{3} \mathrm{BPhen}$ and $\mathrm{Eu}(\mathrm{DBM})_{3} \mathrm{BPhen}:[60] \mathrm{PCBM}$ films were measured and are (a)

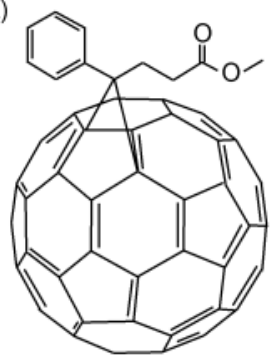

[60]PCBM (b)

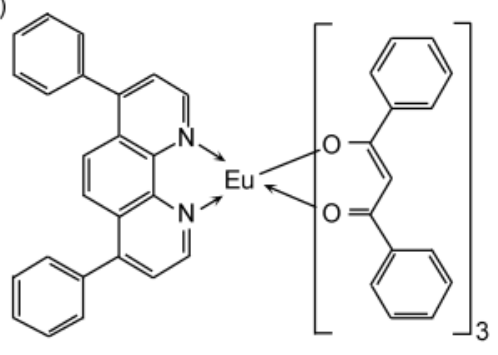

$\mathrm{Eu}(\mathrm{DBM})_{3} \mathrm{BPhen}$ (c)

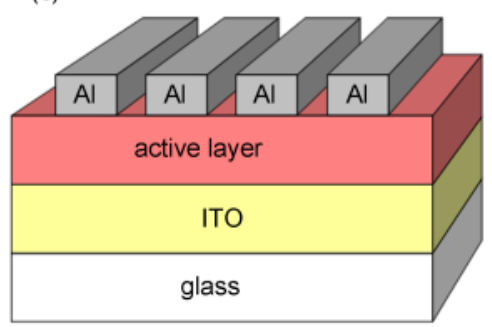

Fig.1 Chemical structures of [60]PCBM (a) and Eu(DBM) $)_{3}$ BPhen (b), schematic diagram of device structure (c) 
shown in Fig.2. The neat $\mathrm{Eu}(\mathrm{DBM})_{3}$ BPhen films show strong and broad absorption from 300 to $400 \mathrm{~nm}$, and the absorption peak is about $358 \mathrm{~nm}$. The absorption intensity of Eu $(\mathrm{DBM})_{3} \mathrm{BPhen}:[60] \mathrm{PCBM}$ films was increased due to the absorption of [60]PCBM. It is known that the organic material [60]PCBM is a kind of high efficient electron acceptor material used in organic photovoltaic cells, which has an apparent absorption peak at $350 \mathrm{~nm}$ in the UV light range. ${ }^{9,10}$ The responsivity of UV-PDs relies intensively on the absorption wavelength, the charge carrier transfer, and the carriers collecting by the two electrodes. Strong UV absorption of photoresponsive materials is an important characteristic of UV-PDs which can ensure the accurate qualitative and quantitative determination of UV light. The photoluminescence (PL) spectra of neat $\mathrm{Eu}(\mathrm{DBM})_{3} \mathrm{BPhen}$ film were measured under the excitation of $360 \mathrm{~nm}$ light (as shown in Fig.3), the $\mathrm{Eu}^{3+}$ characteristic emissions peaking at 576, 589,611,648, and $696 \mathrm{~nm}$ are obtained, which are corresponding to the five energy level transitions of ${ }^{5} D_{0}-{ }^{7} F_{j}(j=0,1,2,3,4)$ of europium ions, respectively. The intense emission from $\mathrm{Eu}^{3+}$ ion is due to the high efficient and ultrafast intramolecular energy transfer from the ligand to $\mathrm{Eu}^{3+}$ ion. ${ }^{11,12}$ However, the PL emission of $\mathrm{Eu}(\mathrm{DBM})_{3} \mathrm{BPhen}$ film is totally quenched by doping [60]PCBM. The inserted images of Fig. 3 show the pictures of $\mathrm{Eu}(\mathrm{DBM})_{3} \mathrm{BPhen}$ and $\mathrm{Eu}(\mathrm{DBM})_{3} \mathrm{BPhen}$ : [60]PCBM solution under the excitation of ultraviolet light. It is apparent that the bright red emission of $\mathrm{Eu}(\mathrm{DBM})_{3} \mathrm{BPhen}$ could not be observed in the blend solution. It means that the blend films should have a highly photosensitive characteristic due to the sufficient absorption of UV light and distinct PL quenching $\mathrm{Eu}(\mathrm{DBM})_{3} \mathrm{BPhen}:[60] \mathrm{PCBM}$ blend films. The photoluminescence excitation spectrum of $\mathrm{Eu}(\mathrm{DBM})_{3} \mathrm{BPhen}$ films was measured by monitoring the emission peak at $611 \mathrm{~nm}$, the efficient excitation wavelength is about $360 \mathrm{~nm}$, which accords with its absorption peak. According to Huang's report, the absorption peak and PLE peak at $\sim 360 \mathrm{~nm}$ are attributed to dibenzoylmethane (DBM) ligand. ${ }^{13,14}$ It is worthwhile to mention that the blend films show very weak absorption in the visible light range. The blend films show great potential application in the VB-UV OPDs due to the strong absorption in UV light range

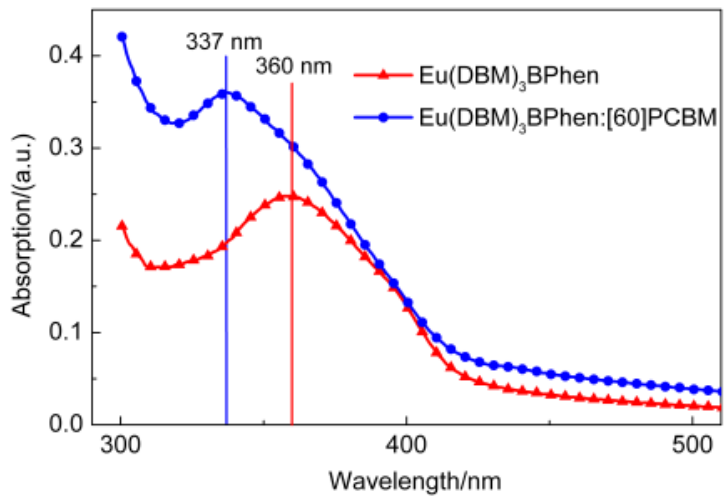

Fig.2 Absorption spectra of Eu(DBM $)_{3} B P h e n:[60] P C B M$ $(1: 1)$ and neat $\mathrm{Eu}(\mathrm{DBM})_{3}$ BPhen films

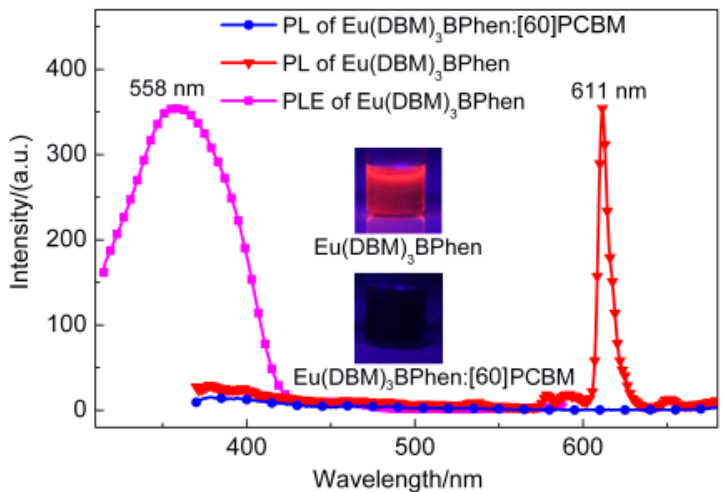

Fig.3 PL spectra of neat $\mathrm{Eu}(\mathrm{DBM})_{3} \mathrm{BPhen}$ and Eu(DBM $)_{3}$ BPhen:[60]PCBM (1:1) film and PLE spectrum of pure $\mathrm{Eu}(\mathrm{DBM})_{3} \mathrm{BPhen}$ film

Insert images are the pictures of $\mathrm{Eu}(\mathrm{DBM})_{3} \mathrm{BPhen}$ and

Eu(DBM) ${ }_{3}$ BPhen:[60]PCBM (1:1) solution excited by ultraviolet light.

and apparent emission quenching by doping [60]PCBM.

The exciton dissociation efficiency is co-determined by exciton lifetime and the phase separation of donor/acceptor. ${ }^{15}$ The heterojunction of donor/acceptor supplies more interface for exciton dissociation to obtain free charge carrier. The emission lifetime of $\mathrm{Eu}(\mathrm{DBM})_{3} \mathrm{BPhen}$ was measured by time resolved transient spectrum, as shown in Fig.4. The emission lifetime $(\tau)$ of $\mathrm{Eu}(\mathrm{DBM})_{3} \mathrm{BPhen}$ is about $300 \mu \mathrm{s}$, which could be obtained from the photoluminescence decay curves according to the single exponential fitting equation: $I(t)=I_{0} \exp (-t / \tau)$. This long lifetime can be expected to reduce exciton recombination and improve exciton dissociation efficiency. The blend of $\mathrm{Eu}(\mathrm{DBM})_{3} \mathrm{BPhen}$ and [60]PCBM films show a significant quenching of PL, representing effective photo-generated exciton dissociation process at D/A interface. Kajii et al. ${ }^{16}$ reported a kind of solution-processed organic PDs with Ir complexes, the photoelectric conversion efficiency was enhanced by doping phosphorescent dyes in poly(dioctylfluorene-co-benzothiadiazole) (F8BT).

In order to further demonstrate the contribution of [60]PCBM to the performance of OPDs, two kinds of OPDs were fabricated with different active layers under the same conditions, device I: ITO/Eu(DBM $)_{3}$ BPhen/Al, II: ITO/Eu(DBM $)_{3} B P h e n:$

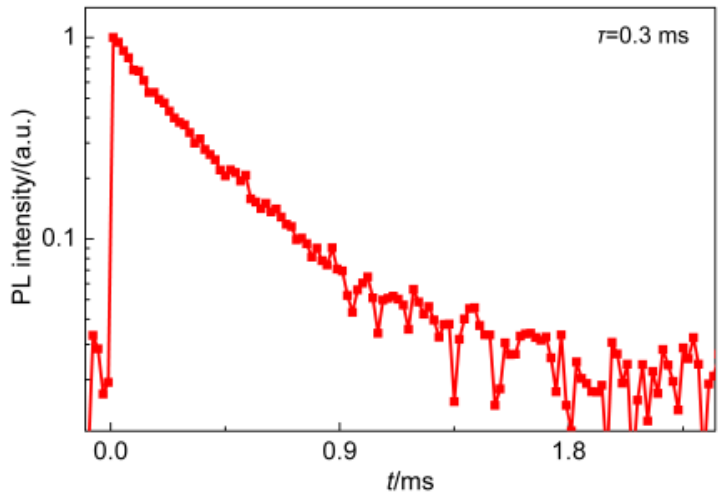

Fig.4 Time-resolved transient PL decay of $\mathrm{Eu}(\mathrm{DBM})_{3} \mathrm{BPhen}$ film by monitoring $611 \mathrm{~nm}$ 
[60]PCBM/Al. Fig.5(a) shows the current density versus driving voltage $(J-V)$ curves of device I under UV light and dark conditions. The $J-V$ characteristic curves of device I show very similar characteristics under UV light excitation and dark conditions. It means that the stead state photocurrent can not be generated in the device I under UV light illumination. It is known that the rare earth complexes are discrete luminescent centers, the charge carrier transfer of intermolecular is very limited due to highly efficient intramolecular charge carrier transfer from ligand to rare earth ions. Fig.5(b) shows the $J-V$ curves of device II under $360 \mathrm{~nm}$ UV light and dark conditions, it is apparent that device II shows distinct photocurrent under UV light illumination. The distinct photocurrent increase of devices II should be attributed to the $\mathrm{Eu}(\mathrm{DBM})_{3} \mathrm{BPhen}$ exciton dissociation induced by [60] $\mathrm{PCBM}$ and high electron mobility of [60]PCBM. ${ }^{17}$ It is well known that reverse bias voltage is an external field applied on the PDs and the electric field direction is identical with that of the built-in field between two electrodes. The increased electric field strength is beneficial to charge carrier transporting and collection.

The transient photocurrents of device II under UV-on and UV-off states were measured under different bias voltages, as shown in Fig.6. The photocurrent density of device II under 0 $\mathrm{V}$ bias voltage is only $4.5 \times 10^{-2} \mathrm{~mA} \cdot \mathrm{cm}^{-2}$ under the $360 \mathrm{~nm} \mathrm{UV}$ light of $2.1 \mathrm{~mW} \cdot \mathrm{cm}^{-2}$. The photocurrent density of device II applied $-5 \mathrm{~V}$ bias voltage shows a fast increase trend until the
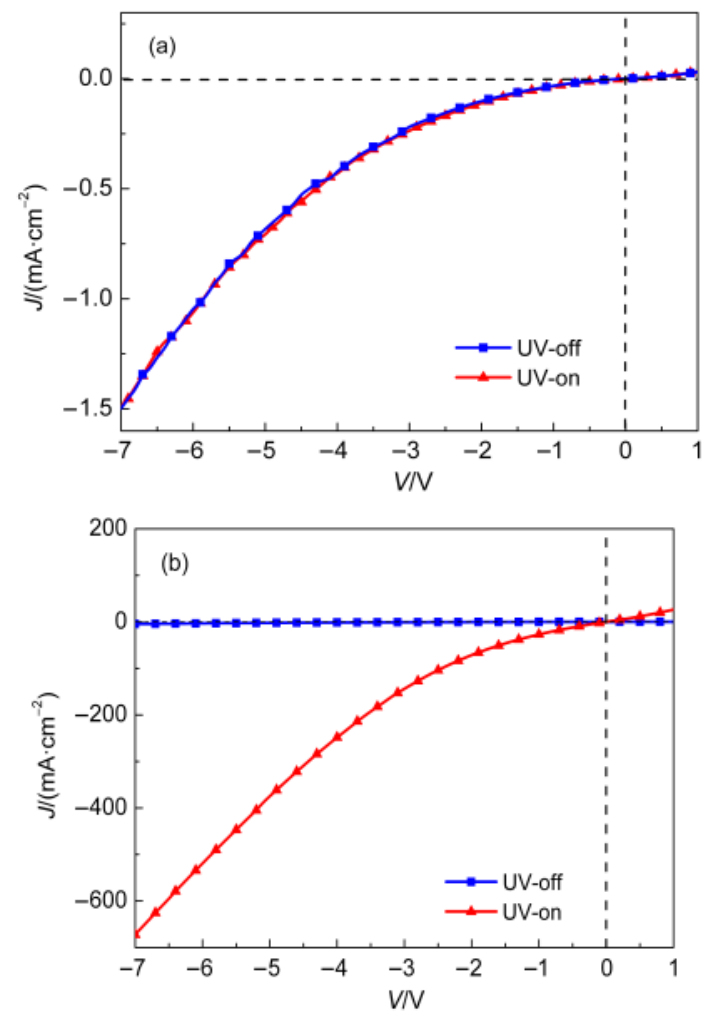

Fig.5 $J-V$ characteristic curves of devices in dark and under $360 \mathrm{~nm}$ UV light illumination conditions

(a) device I, (b) device II
UV light excitation time arrives to $250 \mathrm{~s}$. The fast increase of photocurrent density should be attributed to the generation and collection of charge carrier resulting from exciton dissociation under the applied electric field. Along the increase of UV light excitation time, the photocurrent density shows a slow increase trend from 330 to $350 \mathrm{~mA} \cdot \mathrm{cm}^{-2}$. It could be attributed to the limited charge carrier transporting under high charge carrier concentrations; meanwhile the charge carrier number keeps constant after long time UV light excitation. It means that the dynamic balance between exciton generation and exciton dissociation is arrived after 5 min UV light excitation. When the UV light was turned off, the photocurrent began to decrease and a strong persistent photoconductivity (PPC) was observed due to the high charge carrier concentration and low charge carrier mobility or transporting in the blend films. The low charge carrier transporting ability of blend films could be demonstrated by the current density of $2.9 \mathrm{~mA} \cdot \mathrm{cm}^{-2}$ at $-5 \mathrm{~V}$ bias voltage, as shown in the $J-V$ curve of device II without UV light excitation conditions. PPC phenomenon is a light-induced change in the free carrier concentration which persists once the light excitation is turned off, which was observed in inorganic semiconductor materials ${ }^{18-22}$ and organic semiconductor materials. ${ }^{23-25}$ PPC phenomenon may be related to the low charge carrier transporting, high trap states, and high charge carrier concentration in the blend films. Under the excitation of UV light, the excitons were generated and trapped in the trap states having low
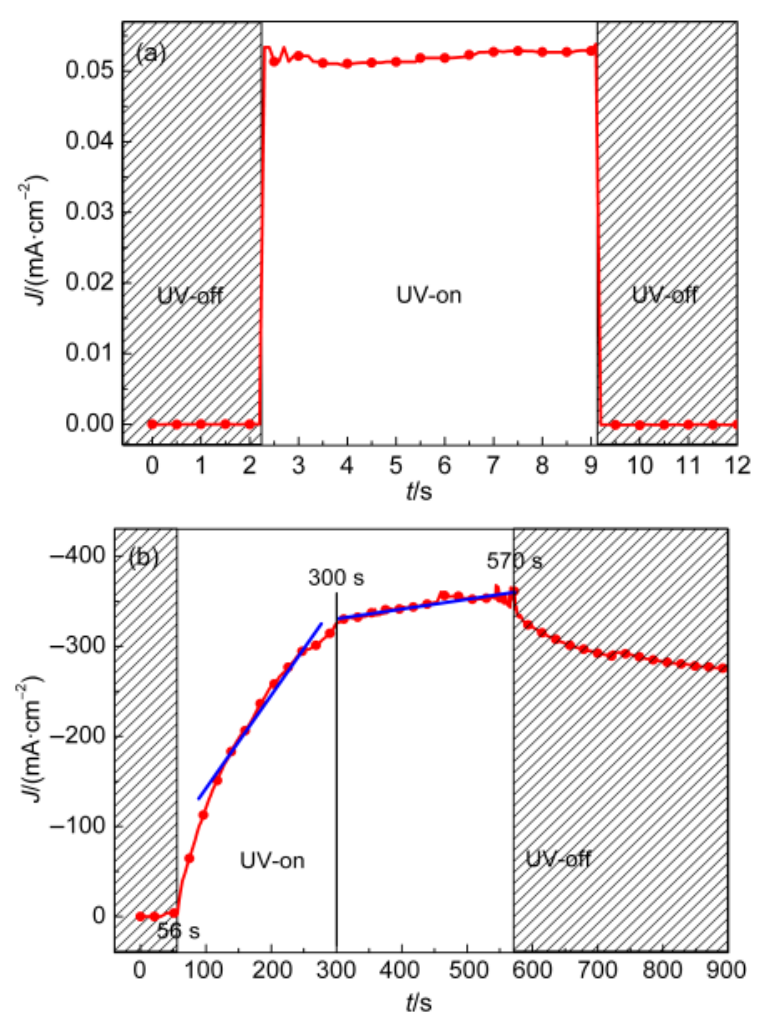

Fig.6 Relationship between current density of device II and the excitation times under $360 \mathrm{~nm}$ UV light illuminations at $2.1 \mathrm{~mW} \cdot \mathbf{c m}^{-2}$ or dark conditions bias voltage/V: (a) 0 , (b) -5 


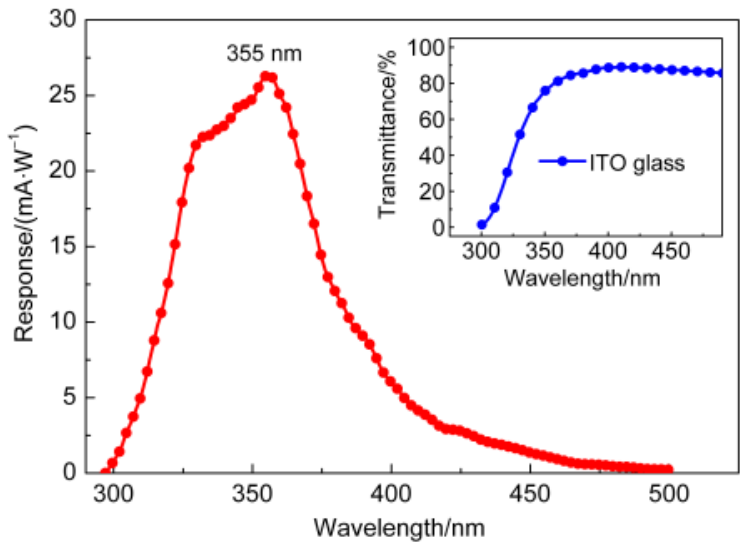

Fig.7 Photocurrent spectral response of device II at $0 \mathrm{~V}$ bias voltage

Insert shows the transmittance spectrum of ITO coated glass substrate.

and high barrier energies. On the other hand, the PPC could be also attributed to photo-generated exciton traps. The excitons trapped at the states with lower barrier energies could be quickly released by the applied electric field when the UV-light was turned off. Kim et al. ${ }^{25}$ also reported that the excitons with higher barrier energies can be also released gradually after UV-light was turned off.

The photocurrent spectral response of device II at $0 \mathrm{~V}$ bias voltage was measured and is showed in Fig.7. The transmittance spectrum of ITO coated glass substrate is shown in the insert image of Fig.7. The device II shows a strong and broad photocurrent spectral response range in UV light region, and a response peak is at $360 \mathrm{~nm}$, which accords with its absorption spectra and PL excitation spectra. The maximum response is $26 \mathrm{~mA} \cdot \mathrm{W}^{-1}$ and the external quantum efficiency (EQE) is $9.1 \%$ under the $360 \mathrm{~nm} \mathrm{UV} \mathrm{light} \mathrm{with} 2.1 \mathrm{~mW} \cdot \mathrm{cm}^{-2}$. Response $(R)$ is defined as $R=I_{\mathrm{p}} / P_{\text {in }}$, where $I_{\mathrm{p}}$ is the absolute value of photocurrent and $P_{\text {in }}$ is the power of incident UV light. EQE is defined as $\mathrm{EQE}=R \hbar v / q$, where $\hbar=h / 2 \pi, h$ is Planck constant, $v$ is the photon energy of incident light, and $q$ is absolute value of electron charge. The response cut- off was observed at $\sim 300 \mathrm{~nm}$ and invisible region, respectively. The sharp response cut-off at $\sim 300 \mathrm{~nm}$ is due to the transmittance cut-off of ITO coated glass substrate at $\sim 300 \mathrm{~nm} .{ }^{26}$ The response cut-off in visible region is due to the weak absorption of $\mathrm{Eu}(\mathrm{DBM})_{3} \mathrm{BPhen}:[60] \mathrm{PCBM}$ in the visible light range. The transmittance of ITO coated glass substrate is over $80 \%$ for the light with wavelength longer than $350 \mathrm{~nm}$. The transmittance of ITO coated glass substrate is less than $2 \%$ for the light with wavelength shorter than $300 \mathrm{~nm}$, which limits the spectral response of fabricated PDs for the light wavelength less than $300 \mathrm{~nm}$. The further research will focus on the novel substrates having high transmittance from 200 to $400 \mathrm{~nm}$ light ranges.

\section{Conclusions}

The VB-UV PDs based on Eu(DBM $)_{3}$ BPhen as a donor and [60]PCBM as an acceptor show a peak response of $26 \mathrm{~mA}$.
$\mathrm{W}^{-1}$ and external quantum efficiency of $9.1 \%$ under the illumination of $360 \mathrm{~nm} \mathrm{UV} \mathrm{light} \mathrm{with} 2.1 \mathrm{~mW} \cdot \mathrm{cm}^{-2}$. Distinct photoluminescence quenching and photoconductivity of $\mathrm{Eu}(\mathrm{DBM})_{3} \mathrm{BPhen}$ were obtained by doping with [60]PCBM. The fabricated organic VB-UV PDs shows a strong persistent photoconductivity induced by low charge carrier transporting and the release of trapped exciton states in the blend films.

\section{References}

(1) Forrest, S. R. Nature 2004, 428, 911. doi: 10.1038/nature02498

(2) Gong, X. O.; Tong, M. H.; Park, S. H.; Liu, M.; Jen, A.; Heeger, A. J. Sensors 2010, 10, 6488. doi: 10.3390/s100706488

(3) Wu, S. H.; Li, W. L.; Chu, B.; Lee, C. S.; Su, Z. S.; Wang, J. B.; Ren, Q. J.; Hu, Z. Z.; Zhang, Z. Q. Appl. Phys. Lett. 2010, 97, 023306. doi: $10.1063 / 1.3463483$

(4) Zhu, L.; Dai, Q.; Hu, Z. F.; Zhang, X. Q.; Wang, Y. S. Opt. Lett. 2011, 36, 1821. doi: 10.1364/OL.36.001821

(5) Zhu, L.; Wang, W. S.; Yao, Z. G.; Zhang, X. Q.; Wang, Y. S. IEEE Trans. Electron Devices 2012, 59, 3583. doi: 10.1109/ TED.2012.2219864

(6) Zhang, J. L.; Nan, Y. X.; Li, H. G.; Qiu, W. M.; Yang, X.; Wu, G.; Chen, H. Z.; Wang, M. Sensors and Actuators B: Chemical 2012, 162, 321. doi: 10.1016/j.snb.2011.12.088

(7) Kalyani, N. T.; Dhoble, S. J. Renewable \& Sustainable Energy Reviews 2012, 16, 2696. doi: 10.1016/j.rser.2012.02.021

(8) Canzler, T. W.; Kido, J. Org. Electron 2006, 7, 29. doi: 10.1016/ j.orgel.2005.10.004

(9) Zhang, F. J.; Zhuo, Z. L.; Zhang, J.; Wang, X.; Xu, X. W.; Wang, Z. X.; Xin, Y. S.; Wang, J.; Wang, J.; Tang, W. H.; Xu, Z.; Wang, Y. S. Solar Energy Materials and Solar Cells 2012, 97, 71. doi: 10.1016/j.solmat.2011.09.006

(10) Zhang, F. J.; Xu, X. W.; Tang, W. H.; Zhang, J.; Zhuo, Z. L.; Wang, J.; Wang, J.; Xu, Z.; Wang, Y. S. Solar Energy Materials and Solar Cells 2011, 95, 1785. doi: 10.1016/j.solmat. 2011.02.002

(11) Zhuo, Z. L.; Zhang, F. J.; Lv, Y. G.; Xu, Z.; Lu, L. F.; Li, J. M.; Wang, Y. S. Phys. Scr. 2010, 82, 055703. doi: 10.1088/00318949/82/05/055703

(12) Li, B.; Ma, D. G.; Zhang, H. J.; Zhao, X. J.; Ni, J. Z. Acta Phys. -Chim. Sin. 1998, 14, 305. [李 斌, 马东阁, 张洪杰, 赵晓江, 倪嘉缵. 物理化学学报, 1998, 14, 305.] doi: 10.3866/ PKU.WHXB19980404

(13) Huang, L.; Cheng, L.; Yu, H.; Zhou, L.; Sun, J.; Zhong, H.; Li, X.; Zhang, J.; Tian, Y.; Zheng, Y.; Yu, T.; Wang, J.; Chen, B. Physica B: Condensed Matter 2011, 406, 2745. doi: 10.1016/j. physb.2011.04.019

(14) Huang, L.; Cheng, L.; Yu, H.; Zhang, J.; Zhou, L.; Sun, J.; Zhong, H.; Li, X.; Tian, Y.; Zheng, Y.; Yu, T.; Li, C.; Zhong, H.; Liu, W.; Zhang, L.; Wang, J.; Chen, B. Opt. Commun. 2012, 285, 1476. doi: 10.1016/j.optcom.2011.10.006

(15) Zhuo, Z. L.; Zhang, F. J.; Xu, X. W.; Wang, J.; Lu, L. F.; Xu, Z. 
Acta Phys. -Chim. Sin. 2011, 27, 875. [卓祖亮, 张福俊, 许晓 伟, 王 健, 卢丽芳, 徐 征. 物理化学学报, 2011, 27, 875.] doi: 10.3866/PKU.WHXB20110414

(16) Kajii, H.; Katsura, A.; Ohmori, H.; Sato, Y.; Hamasaki, T.; Ohmori, Y. J. Non-Cryst. Solids 2012, 358, 2504. doi: 10.1016/j. jnoncrysol.2011.12.097

(17) Li, Y. F. Accounts of Chemical Research 2012, 45, 723. doi: $10.1021 /$ ar2002446

(18) Cai, S.; Parish, G.; Dell, J. M.; Nener, B. D. J. Appl. Phys. 2004, 96, 1019.

(19) Verbakel, F.; Meskers, S. C. J.; Janssen, R. A. J. Appl. Phys. Lett. 2006, 89, 102103. doi: 10.1063/1.2345612

(20) Reyes, P. I.; Ku, C. J.; Duan, Z. Q.; Xu, Y.; Garfunkel, E.; Lu, Y. C. Appl. Phys. Lett. 2012, 101, 031118. doi: 10.1063/1.4737648

(21) Dasgupta, S.; Knaak, C.; Moser, J.; Bichler, M.; Roth, S. F.; Morral, A. F. I.; Abstreiter, G.; Grayson, M. Appl. Phys. Lett.
2007, 91, 142120. doi: 10.1063/1.2794012

(22) Hirsch, M. L. T.; Wolk, J. A.; Walukiewicz, W.; Haller, E. E. Appl. Phys. Lett. 1997, 71, 1098. doi: 10.1063/1.119738

(23) Kim, C. H.; Kisiel, K.; Jung, J.; Ulanski, J.; Tondelier, D.; Geffroy, B.; Bonnassieux, Y.; Horowitz, G. Synth. Met. 2012, 162, 460. doi: 10.1016/j.synthmet.2011.12.021

(24) Nardes, A. M.; Ferguson, A. J.; Whitaker, J. B.; Larson, B. W.; Larsen, R. E.; Maturová, K.; Graf, P. A.; Boltalina, O. V.; Strauss, S. H.; Kopidakis, N. Adv. Funct. Mater. 2012, 22, 4115. doi: 10.1002/adfm.v22.19

(25) Kim, C. H.; Choi, M. H.; Lee, S. H.; Jang, J.; Kirchmeyer, S. Appl. Phys. Lett. 2010, 96, 123301. doi: 10.1063/1.3372619

(26) Li, L.; Zhang, F.; An, Q.; Wang, Z.; Wang, J.; Tang, A.; Peng, H.; Xu, Z.; Wang, Y. Opt. Lett. 2013, 38, 3823. doi: 10.1364/ OL.38.003823 